\title{
PERFORMING THE REAL AND TERRIFYING DOMESTIC CRISIS IN MARTIN MCDONAGH'S THE BEAUTY QUEEN OF LEENANE
}

Esther de la PeÑa Puebla

Universidad de Sevilla

estherdlp@hotmail.com

\begin{abstract}
Martin McDonagh's The Beauty Queen of Leenane portrays a brutal domestic crisis between mother and daughter in an Irish rural household set in Connemara. The raging dissensions in their relationship emerge as a consequence of the load of religious tradition, deep-seated generic mores, and liminal nationalistic ambiguities. The blatant «in-yer-face» drama Maureen incarnates revolves against her fragile hopes for personal realization, and her mother's fight for control. Furthermore, Maureen's frustration and anxiety are deeply intensified by her claustrophobic, murky environment. Thus, McDonagh's contemporary Irish identity distills a strong sense of entropy which struggles to redefine itself through an interwoven, post-colonial Irish heritage, traced by internal strife, diaspora and exile. Ultimately, what is unique to McDonagh's play is his pessimistic voice offering no solution for a better future. His clear, honest and provocative testimony speaks of awareness of the Irish history and its dramatic consequences in the present.
\end{abstract}

KEY WORDS: domestic crisis, Irish identity, in-yer-face theatre, entropy, anxiety.

\section{RESUMEN}

La obra de Martin McDonagh The Beauty Queen of Leenane (La reina de belleza de Leenane) escenifica una brutal crisis doméstica entre madre e hija en una casa familiar 
irlandesa, situada en la región de Connemara. Las violentas confrontaciones que salpican la convivencia de ambas mujeres surgen como resultado de una tradición religiosa y social arraigada, con un trasfondo liminal nacionalista ambiguo e indeterminado. Perteneciente al denominado teatro «in-yer-face», la protagonista del cruento drama, Maureen, se enfrenta al conflicto que emana entre sus frágiles aspiraciones personales y el férreo control que ejerce su madre sobre su vida. La frustración y ansiedad que padece Maureen se ven incrementadas, adicionalmente, por el entorno doméstico claustrofóbico y lóbrego en el que discurre su vida. Así, McDonagh consigue transmitir la entropía existencial que destila la identidad irlandesa contemporánea, que lucha por redefinirse a través de un complejo legado postcolonial, marcado por los conflictos internos, la diáspora y el desarraigo. Finalmente, la originalidad de McDonagh recae en su propia voz, honesta, pesimista y carente de esperanza. Su testimonio, provocador y lacerante, habla de la conciencia histórica irlandesa, y sus dramáticas consecuencias en el presente.

Palabras Clave: crisis doméstica, identidad irlandesa, teatro «in-yer-face», entropía, ansiedad.

\section{INTRODUCTION}

«For man never reasons so much and becomes so introspective as when he suffers, since he is anxious to get at the cause of his sufferings, to learn what has produced them, and whether it is just or unjust that he should have to bear them»

Pirandello: Six Characters in Search of an Author.

The Irish-born, London based dramatist and screenwriter Martin McDonagh spent most of his summer holidays with his family in Connemara, a rough region of West Ireland that captivated him by its moon-shaped features and remoteness (O'Toole, 2010: 1). If Oscar Wilde would recall Connemara as «a savage beauty», and Yeats as «a landscape of dreams and imagination» (Kiberd, 2006: 364), McDonagh has a much less romantic conception of the place. As a matter of fact, Connemara makes the perfect setting for McDonagh's stories: outlandish and abrupt. First of a trilogy, all set in the mountains of Connemara, the The Beauty Queen of Leenane is a domestic drama, loaded with Irish humor and suspense, which tells the gloomy story of Maureen Folan, a neglected and frustrated spinster in her early forties, and Mag, her wicked and controlling aging mother: «Interfering with my life again? Isn't it enough I've had to be on beck and call for you every day for the past twenty years?» (377). Mag's intrusion and obstruction in her daughter's one and only romantic relationship unleashes a series of events that lead dramatically towards the play's inevitable end. MacDonagh presents the reader/audience a domestic drama that transcends the cruel relationship between mother and daughter. He portrays, in an appalling way, the brutality human beings are capable of when they feel that violence is the only tool they can make use of in reaction to an unbearable existence. Additionally, I maintain that in The Beauty Queen McDonagh intertwines components of Irish nationalism, classic realism, and in-yer-face drama. Also inspired in the Gothic genre and the popular horror film Psycho, McDonagh exceptionally outlines the historically complex, post-colonial Irish reality, mostly defined by domestic strife and exile. 


\section{Understanding Mcdonagh's Contemporary Drama}

«I find joy in life in its violent and cruel struggles, and my pleasure lies in knowing something and learning something».

August Strindberg, October 1888

According to Heath A. Diehl (2001), the history of Irish theatre has always been «linked to the island's colonization by England» (p. 102). Thus, Irish drama has often proved to be useful in its content, for it «[would become] at times a means for propaganda, but ultimately the means by which the deeper life of the people is expressed» (O’Driscoll 1971: 12).

During the nineteenth century, Irish theatre was basically concerned with melodrama, which aimed to present the audience plays where life appeared «in a time of political, social, and artistic deprivation as [the nation] would want it to be rather than life as it was» (O'Driscoll 1971: 13). By the end of the nineteenth century, interest in Irish folklore and Irish language (Gaelic) unleashed a deep nationalistic passion which was to culminate with the foundation of an Irish theatre. The three major founders were of Anglo-Irish ${ }^{1}$ origin: Yeats, Lady Gregory, and Martyn. Their purpose, as Lady Gregory declared, was to «bring upon the stage the deeper thoughts and emotions of Ireland [...] carrying out a work that is outside the political questions that divide us» (Lady Gregory 1914: 8-9). As new playwrights emerged, new literary and theatrical forms started to confront the bucolic idealism of the peasantry. Although Gaelic was encouraged from the State to be performed in plays, English remained as the leading language in drama (Fitz-Simon 1983: 138). The Irish National Theatre was firmly supported by Yeats and Annie Horniman, who would finally «provide and equip a small theatre in Dublin and maintain it free of charge for a number of years» (Fitz-Simon 1983: 140). That was the Abbey Theatre, and that would be the beginning of a new era for drama.

By the beginning of the twentieth century, along with strong feelings of upcoming independence and new concerns about the nation, playwrights started to abandon the classic melodramatic themes which had characterized Irish drama. Ireland then appears as a matter of discontent and contradiction, and authors «felt called upon to do battle for what it believed to be the honour of the nation» (O'Driscoll 1971: 9-10). Plays like those of John Millington Synge and Sean O'Casey suddenly turned Ireland into the land of violent farmers and drunken peasants. Daily life is thus presented as deprived of idealism, with characters «whose only weapons for survival were not 'fabricated' idealisms but their own native cunning and their own native wit» (O'Driscoll 1971: 14). Synge and O'Casey opened a new path for contemporary playwrights, who, like Martin McDonagh, have continued challenging the Irish melodramatic tradition, and have further contributed to the process of demythologization of Ireland.

\footnotetext{
1 «Anglo-Irish» describes the upper social class in Ireland, called the Anglican social elite. Members were the descendants of the Protestant Ascendancy, and share faith in the Anglican Church of Ireland (the official state church of Ireland until 1871). The «Protestant Ascendancy» describes the group of rich landowners, members of the church, and other workers who were part of the political, economic, and social domination of the former Kingdom of Ireland (Blackwell and Hackney, 2004: 93-94).
} 
At the end of the twentieth century, during the ninety nineties, a new type of British drama appeared: «drama that takes the audience by the scruff of the neck and shakes it until it gets the message» (Sierz, 2000: 4). Referred to as «in-yer-face theatre», this kind of plays aim at provoking readers/ audience, stirring unsettling emotions that will not leave spectators indifferent. As Alek Sierz has declared: «the language is usually filthy, characters talk about unmentionable subjects, take their clothes off, have sex, humiliate each another, experience unpleasant emotions, become suddenly violent» (Sierz, 2000: 5). In that light, authors like Martin McDonagh respond to that kind of drama with plays that portray characters who are victims of their own oppression, and feel unable to achieve their goals, for their circumstances are usually suffocating. Cruelty then appears as the unifying factor in the plays, which enable characters to express their brutal feelings against futility. McDonagh, however, goes beyond the paradigm of «in-yer-face» playwrights, and he rejuvenates the quest for authenticity through a more complex blending of theatrical strains.

\section{FROM IRISH NATIONALISM TO REALISM IN POST-MODERN IRELAND}

David Hirst states that «The strength of modern drama resides chiefly in its discovery of fresh theatrical structures which serve a serious ethical and social purpose» ${ }^{2}$. In that sense, the tensions and the conflicts that Martin McDonagh transmits in his plays are articulated and interwoven around his Irish heritage and London rootedness. This hybrid combination unveils the playwright's liminal national identity which provides generic innovations at the core of his play. McDonagh subverts and unsettles the very foundational principles of Irish nationalism, starting with the nuclear family. As Kathryn Conrad has remarked, «If the [family] cell is stable, so too are the social institutions built upon it, and one can present to the world one's capacity to rule. Instabilities must therefore be constructed and treated as foreign-not only to the family, not only to one's political position, but also to the nation as a whole. $\gg^{3}$ In that light, McDonagh deprecates and satirizes the role of the traditional family and its relationships as part of a demythologizing project. The first scene of the play already presents the bitter dysfunctional relationship between Maureen (Mag's caretaker for over twenty years) and her mother, Mag, who demands constantly her daughter's attention. Mag: «Me bad back» (p. 364); «Me porridge Maureen» (p. 365); «Me mug of tea you forgot!» (p. 368); «No sugar in this, you forgot, go get me some» (p. 369). Maureen's poignant responses to her incessant petitions are marked with irritation and anger: «You're oul and you are stupid and you don't know what you are talking about» (p. 368);

«I could live with you so long as I was sure he'd [Pato] be clobbering you soon after [...] with a big axe or something and took your head off and spat in your neck, I wouldn't mind at all, going first. Oh no, I'd enjoy it, I would. No more oul Complan to get, and no more oul porridge to get, and no more... (p. 369).

\footnotetext{
${ }^{2}$ David L. Hirst. Tragicomedy. The Critical Idiom, 43. London: Methuen, 1984, pag. 128.

3 Kathryn Conrad. Locked in the Family Cell: Gender, Sexuality and Political Agency in Irish National Discourse. Madison: University of Wisconsin Press, 2004: 10.
} 
Right from the very beginning, the reader/ audience can easily understand Maureen's complaints, given her condition of victim and abused daughter. Maureen's anxiety is also increased by her constant presence at home, in the kitchen, where all the action takes place: «Do you think I like being stuck up here with you? Like a dried up oul...» (p. 378), and wishes: «Of anything! of anything other than this [life]» (p. 378). The cultural reminiscences of «a crucifix and a framed picture of John and Robert Kennedy [emblems of political assassinations] on the wall above the range, a black heavy poker beside the range...» (p. 363), and the embroidered tea towel which reads «May you be half an hour in heaven afore the Devil knows you're dead», reminds the reader of the three classic themes of Irish national history: religion, exile, and family union. The lack of a patriarchal figure in the play reinforces the female role, and perpetuates the traditional barriers the new generations must overcome. As Maureen reminds her mother, men and women «have equality nowadays. Not like in your day» (p. 407); whereas Mag remarks: «There was nothing wrong in my day» (p. 408). That discourse is presented as an integral part of the conflicts Irish society still has to endure concerning women's emancipation. If Julia Kristeva defended the female potentiality to change the symbolic roles imposed by a masculine order in society - «a woman [is] more vulnerable within the symbolic order [...] but both sexes inhabit, shape the form and they have the potential to transform it» (1986: 204), McDonagh, however, refutes that idea portraying the reluctance of a society unable to overcome its own history. Therefore, he plunders the traditional past to portray the stereotype of the Irish maiden waiting for his lover (Pato) to rescue her from subjugation; Pato: «You shouldn't let her [Mag] get to you»; Maureen: «How can I help it, Pato? She's enough to drive anyone loopy» (p. 395). When he proposes Maureen to accompany him to America, she then fantasizes about abandoning the murky and oppressive environment around her: «To Boston. To Boston I'll be going [...] Be it married or be it living in sin, what do I care?... so long as I'm with you, Pato, what do I care...» (pp. 414-5). In that respect, Maureen displays a brightened self-esteem (as Pato crowned her as the «beauty queen», p. 383) and a positive view of her future world (as she was offered a real chance for escape). However, her prospects will soon be crushed when her mother finds out her plans with Pato. Mag's anger is then illustrated violently when the day after the party she «tosses [Maureen's new] dress into a far corner» (p. 388), without thinking of the important meaning that Maureen's reencounter with Pato had for Maureen's future life. However, Mag's refusal to go to a nursing home evidences and preserves the cultural tradition of keeping the family order stable and immutable, as she states: «But how could you go with him? You do still have me to look after» (p. 412). Her strong rooted beliefs will justify the burning of her daughter's love letters, and simultaneously the destruction of Maureen's dreams and hopes for a better future with Pato; thus, Maureen recalls «(dreamily to herself): He asked me to go to America with him?» (p. 413). At that moment, the house then transforms into a prison-like space for Maureen in which she is the prisoner, deprived of the means to encourage her personal realization, and she is left alone with her jailer. Anxiety and desperation will provoke in Maureen the need to avenge the irreparable damage. By the time Maureen is discovered to be the murderer of her own mother, the reader/audience will have already focused on her as the point of identification in the story. Maureen's acts will no longer be object of any moral judgment. «McDonagh not only asks readers/spectators to identify with Mau- 
reen, but, in so doing, he also establishes her as the voice of reason, truth, and morality in the play» (Diehl, 2001: 101-102).

Similarly, McDonagh accomplishes to combine the basic principles of what a nation is or is supported on through the corresponding bases of what is not. As Christopher Murray states, «... in Ireland the nation is staged rather than told» (1997: 6). In Essays on Performance Theory, Richard Schechner argues that theatre is frequently viewed as threatening because it looks into the «problematical, taboo, difficult, liminal and dangerous» (1977: 164). Thus, theatre (as has been argued before) can often portray and reproduce the social discomfort of groups in relation to political issues taken on stage, aiming at confronting realities, and working to change attitudes and behavior. In that respect, Ireland is in a great proportion virtually distinctive as a problematic world being staged in its expression of self. For McDonagh, the construction and representation of the Irish national identity demands the rejection of the people who can be a possible menace to the nation, thus becoming the society's monsters (Hebdige, 2008: 592). By the same token, Nicholas Grene ${ }^{4}$ coined the term «black pastoral» to describe the mutation that the idyllic rural settings in Ireland are progressively undertaking:

What is extraordinary is just how long that demythologization [of the West] has gone on, how much of Irish literature has been devoted to this enterprise. Archaic Ireland is dead but it won't lie down: the fierceness of McDonagh's iconoclasm feels like an effort to kill it at last (2005: 306).

Grene specially argues about the figure of the mother and the nation together: «In watching the murder of the mother [we] can exorcise any sense that we need to venerate where we come from» (p. 307). In that sense, one of the main tropes of Irish nationalist rhetoric identifies the nation as woman: Mother Ireland, or the Poor Old Woman. Thus, Mag clearly represents the stereotype of Irish womanhood, basically a housewife, as supported by the 1937 constitution ${ }^{5}$ : «the State recognizes that by her life within the home, woman gives to the State a support without which the common good cannot be achieved.» However, this obvious link between the mother and the nation goes beyond the mere comparison to develop the plot. Mag unveils a regressive sense of morality and decency, which makes Maureen a «whore» in her eyes for kissing two men: «Two men is two men too much! [...] You girls should not be out gallivanting with fellas...!» (pp. 377-8). Readers may easily infer that this conservative mentality derives from the catholic religion, which appears supported by the clear symbol of the crucifix on the kitchen wall. Mag also appears to be little cognizant of her nation's history, and she shows no patriotic feelings about her country either. Maureen: «What country are you living in?» Mag: «Galway» (p. 366). When she and her daughter are listening to the radio and a man starts singing in Gaelic, Mag calls him: «An oul fella singing nonsense», and complains to Maureen: «Why can’t they just speak English like everybody else?» (p. 366). Maureen then justifies that «It's Irish you should be speaking in Ireland,» but Mag does not seem

\footnotetext{
${ }^{4}$ Nicholas Grene. «Black Pastoral: 1990s Images of Ireland», in Litteraria Pragensia, issue 20, vol. 10, 2000.

— «Ireland in two Minds: Martin McDonagh and Connor McPerson», The Yearbook of English Studies: Irish Writings since 1950. Vol. 35, 2005: 298-311.

${ }_{5}^{5}$ Patrick Hanafin. Constituting Identity: Political Identity Formation and the Constitution in Post-Independence Ireland. Aldershot, Dartmouth, Burlington, Ashgate, 2001.
} 
convinced at all, and ignores her commentary, «I don't know» (p. 367). Clearly, Mag is quite unaware of her Irish rootedness and history, and what being «Irish» might mean for her. She makes evident that she does not know the Irish language either, not being able to identify or recognize the words as such. It is Maureen, the new generation, who can actually support a nationalist sentiment and discourse about the loss of the Irish tongue, as she condemns the English for «stealing our language» (p. 367). In some way, Ireland is present in the figure of Mag, who stands for a country that has become progressively void of meaning, even for the native Irish. It is Maureen who evokes a new version of an Irish identity: «If it wasn't for the English stealing our language, and our land, and our God-knows-what, wouldn't it be we wouldn't need to go over there begging for jobs and for handouts?» (p. 367). In her complaint, she acknowledges the cultural loss the Irish language and land (and everything else Irish) is undertaking. She exposes Ireland as a country unable to manage its own identity, motionless and resigned to accepting the English «stealing» its idiosyncrasy. Similarly, Mag appears as unproductive as Ireland, void of her own Irish culture, and constantly begging for help. This harsh reality is what elucidates the «dream world of the outcast of society, the human condition, the alienation of man, his solitude, and his futile search for meaning and reality» (Esslin, 1961: 167).

If classic realist plays attempt to provide «coherent texts whose transparent language is capable of projecting a stable meaning» (Dolan, 1993: 42), then The Beauty Queen cannot be read according to that principle at all, for it disrupts the regular code of realism ${ }^{6}$. However, McDonagh's play does respond to the tradition of Irish nationalism and angry young «woman» drama, for he presents on stage the deep thoughts, worries, and emotions of Irish people. As a matter of fact, McDonagh mirrors the Irish historical background and its national consciousness dramatically. In that light, and according to Anthony Roche, McDonagh's ironic fusion of the bizarre, macabre, and fantasy connects him to the oral and written Irish comic tradition from its oral roots through its twentiethcentury manifestations ${ }^{7}$. McDonagh also recovers the tradition of Irish drama telling a story by means of subverting and changing stereotypes, from the bucolic Irishman from the West to the sweet idealized Irish lady. The fact that McDonagh's play is set in Connemara reaffirms that his work is deeply rooted in specific regions of the country, and it reveals perceptions and views of everyday life in contemporary Ireland. Furthermore, McDonagh's The Beauty Queen brings about some of the most recurrent themes explored by traditional Irish playwrights, such as family bond and its deconstruction, as can be found in Friel; harsh daily life and its violent representations, like O'Casey; or the rural environment in domestic life, linked with Synge's plays. Although McDonagh's voice is much more pessimistic and less nostalgic, his concerns about Irish life are as traditional as reminiscent of his Irish heritage. McDonagh himself has acknowledged this influence on his plays in an interview with Mimi Kramer in August 1997: «It's not that I don't consider myself an Irish writer. I just try to avoid any questions of nationality or nationalism. I've always felt kind of in between. I'm more of a London boy than anything else, but you

\footnotetext{
${ }^{6}$ In drama, realism usually poses questions in the first part of the play which are solved in the second half. In Beauty Queen the dilemmas raised are not solved, but left open-ended.

7 Anthony Roche. «Re-Working the Workhouse Ward: McDonagh, Beckett, and Gregory». Irish University Review, 34.1-2, Spring/ Summer 2002: 171-84.
} 
can't help having those Irish leanings» (71). Even though McDonagh explicitly points out his liminality (his in-between-ness) in his treatment of themes and traditional Irish topics, his «Irish leanings» are also evidenced in other aspects. Quite representative of that liminality that blurs the borderlines emerges when McDonagh abandons the realist frame in the second act of Beauty Queen, and he deliberately makes a choice for an ambiguous and unresolved narrative, as part of an illustration of what O'Toole calls McDonagh's «multiple differences» (1998: 17). For O’Toole, McDonagh articulates the implicit meanings of the adjective «Irish» in diverse forms throughout his plays. Thus, the dramatic tension McDonagh builds between Maureen's frustration to become independent, and Mag's strong codependence, reaches its climax in scene eight, when Maureen (after torturing her mother) bludgeons her to death with a fireplace poker. Whereas in a realistic play the murder would have relieved Maureen from her subjugation to her mother, McDonagh disclaims to support a response to what performance academic Elin Diamond has defined as realism being «equivalent of a grand mal seizure: the confession» (1997: 24). Therefore, McDonagh opts to complicate the dramatic force and anxiety by the end of the play, avoiding to provide the reader/ audience with an explanation and/or resolution to a situation that appears to be recurrent, and thus, irresolvable. Consequently, Maureen's mother continues to ghost the stage after death, as if she would return from the grave, a device that is represented in the empty chair «still rocking gently» as the «lights, very slowly, fade to black» (p. 425). This figurative image, the constant presence-absence of Mag, whether delusive or real, suggests the unhealthy barbaric bond between mother and daughter, as a continuous, open-ended relationship, unable to achieve closure. Clearly, McDonagh portrays the impossibility to sustain a coherent, stable personality when this is confronted with the paralysis of a society that impinges one's life. This situation is dramatically emphasized in Maureen's characterization in scene nine, during her conversation with Ray. She undergoes a transformation that shows nuances of her mother's personality, thus becoming puzzled and disoriented. As Maureen says: «(standing confused) I did see him the night he left...» (p. 420); Ray: He looks at her as if she's mad. «Aye, aye. (mumble sarcastic) (p. 420). Maureen's blurring border between sanity and madness reminds the reader/ audience of her mother and herself in a constant flow of enigmatic and selfcentered comments. Closely related to that splitting personality is Homi Bhabha's ${ }^{8}$ theory of the stairwell as liminal space within the domestic environment: «The hither and thither of the stairwell, the temporal movement and passage that it allows, prevents identities at either end of it from settling into primordial polarities» (1994: 5). Therefore, Maureen moves through a domestic space that connects her past with her irreversible future in unceasing movements. Ray's bewilderment about Maureen will conclude with the acknowledgement of «The loons you do get in this house! Only repeating!» (p. 422); and his final conclusion: «The exact fecking image of your mother you are, sitting there pegging orders and forgetting me name! Goodbye!» (p. 424). Maureen's sense of identity appears provisional and mysterious, raising questions without providing answers. The play thus remains locked in enigma, offering a «realism without truth», a device which «does not abandon narrative, but... refuses the closure of positivist inquiry» (Diamond, 1997: 37).

\footnotetext{
${ }^{8}$ Homi Bhabha. The Location of Culture. London: Routledge, 1994.
} 
The fact that McDonagh's play appears to be fractured and unpredictable in its structure and characters do not necessarily indicate that they have superseded the paradigm of Irish national identity. Quite on the contrary, The Beauty Queen remains faithful to the classic realism of Irish plays in its representation of a traditional domestic world in which the new forms of modernity undermine, and deconstruct the nationalistic spirit, in order to evidence the nation's destabilization and confusion. In that respect, McDonagh portrays an extreme postmodern Irish society, deconstructed and isolated, as part of a globalized world in which people make use of violence in a futile attempt to manage their lives.

\section{MCDONAGH'S DISSAPPOINTMENT: LOOKING BACK IN «YER-FACE»}

«If you've no world of your own, it's rather pleasant to regret the passing of someone else's. I must be getting sentimental. But I must say it's pretty dreary living in the American Age $=$ unless you're an American of course».

John Osborne's Look Back in Anger

If the reading of McDonagh's The Beauty Queen provides a link to understand contemporary Ireland through its structure and fractured characters, McDonagh also reveals traces of traditional angry young woman/man drama, which contribute to account for a final «in-yer-face» representation. The frustration and disappointment Maureen and Pato experience in the play emerge as a consequence of the impossibility to sustain the deep-seated generic mores in their changing society. Likewise, the new construction of Irish identity appears to be marked by the blurring of geographical boundaries. In that sense, Pato, like McDonagh, is an outsider, and both identities are constructed in their Anglo-Irish liminality. However, whereas for McDonagh his writings manifest the «conditions and parameters of national identity in the context of globalization» (Diehl, 110), Pato's need for belonging is expressed in his mournful speech: «I do ask meself, if there was good work in Leenane, would I stay in Leenane? [...] But when it's here I am... it isn't there [in London] I want to be, of course not. But I know it isn't here I want to be either» (385). Despite the tone, Pato does not evoke feelings of nostalgia, but rather disappointment for not being able to find a place where he yearns to belong. The many possibilities of this hybrid experience of interstitial spaces are widely explored in Homi Bhabha's (1994). In that sense, the rough region of Connemara, especially the village of Leenane, frames a post-colonial landscape which portrays confusion and ambiguity, rendered unbalanced by the constant dislocation, exile and diaspora. Far from being characterized by the «Utopian moment» of «the second coming» (Bhabha, 1994: 18), McDonagh's work is marked by the constant remapping of dysfunctional traditional spaces (home, county, nation), and identities (family members, Irish citizens) in a new dynamic postcolonial present. This fractured world between spaces and identities alters the reader/audience's perceptions and provokes unsettlement and expectation. Thus, characters appear embittered and disoriented, struggling to redefine themselves, and being forced to look back in disappointment; Pato: «Of course, it's beautiful here [Leenane], a fool can see. The mountains and the green, and people speak. But when everybody knows everybody else's business [...]. In England, they don't care if you live or die, and it's funny but that isn't altogether a bad thing» (385). 
The hopelessness that McDonagh has progressively instilled in his characters will lead them to a sense of inevitable nihilism ${ }^{9}$, which will also account for the cruelty they display. In that context, the main elements of «in-yer-face» theatre (language, cruelty, and lack of morality) take special relevance, as they help McDonagh build up the dramatic tension in Beauty Queen. The use of offensive language interlacing swearing and cursing appears from beginning to end, increasing aggression and making anger evident; Maureen: «Just a [...] blessed fecking skivvy is all I'm thought of!» (365); Ray: «I should've fecking written it down in the first fecking place, I fecking knew! And save all this fecking time!» (373). Likewise, the incessant exchange of heartless brutal acts between mother and daughter increase the tension, and contribute to the threat of an imminent death. McDonagh transforms common, daily objects such as Complan, Kimberleys, cooking oil and a fireplace poker into instruments of abuse, torment, and murder. In scene three, Maureen confesses Pato that she buys the terrible Kimberley biscuits only to torment her mother (p. 382). Additionally, when Mag confesses Maureen having lied about Pato's invitation, Maureen obliges her mother to drink another bowl of lumpy Complan, «The whole of it now!», even though Mag had already taken it, and constantly complains of feeling a «funny tummy» (p. 377). Maureen unfolds «Real and terrifying [identifying with] the emotional palsy of a people trapped in their own unrealized dreams» (Waters, 2001: 51). So, when Mag's murder is revealed in scene eight, the mixed emotions that readers/audience experience about Maureen unsettles their conventional moral judgment. As Aleks Sierz writes about The Beauty Queen, «the play's violence is not just a comment on domestic life in a suffocating backwater; it also creates a world drenched in a nineties sensibility», where violence and alternative lifestyles were breaking the traditional role models (2000: 223). All the initial verbal dissensions between Maureen and Mag will progressively escalate up to a point where physical torture and murder will replace offensive language.

The oil has started boiling. Maureen rises, turns the radio up, stares at Mag as she passes her, takes the pan off the boil and turns the gas off, and returns to Mag with it [...]. Maureen slowly and deliberately takes her mother's shrivelled hand, holds it down on the burning range, and starts slowly pouring some of the hot oil over it, as Mag screams in pain and terror (p. 411-12).

Another feature which responds to the «in-yer-face» theatre, and also appears in The Beauty Queen is the utter lack of moral values of central characters. In the case of Mag, she cannot even grant her own daughter the life she has been waiting for, and be happy for her. As for Maureen, torture will be the only means to find out the truth about Pato, and murder her way to avenge herself on her mother. In either case, she will show no moral regret or dilemma, thus portraying her malice and brutality.

McDonagh's The Beauty Queen also accounts for the infiltration and bastardization of Irish culture through television: American shows, Australian soap operas and British sitcoms are influences that are causing irreversible shifts in lifestyles. A clear reminder of

\footnotetext{
9 According to Ken Urban, «... cruelty, and nihilism come together to form an ethical vision, as opposed to a moral one, and in the process cruel Britannia conjures a contemporary experience of the tragic for audiences at the end of the bloodiest of centuries»(355). In «Towards a Theory of Cruel Britannia: Coolness, Cruelty, and the 'Nineties». New Theatre Quarterly, 2004, 20, pp. 354-372.
} 
the American influence is the picture of the Kennedy brothers when they visited Ireland in 1963. That image has a present continuity in Pato emigrating to the U.S.A., thus illustrating how Irish people have been exported under the influence of other industrial and economic powers. Both Maureen and Pato have suffered the consequences of emigration and bad working conditions, thus making them resentful; Maureen: «In England I was [...] I'd say: To come to this place cleaning shite?» (p. 395), and Pato: «In London and working in rain and it's more or less cattle I am» (p. 385). They both acknowledge the harsh conditions they had to bear, and the repercussions of such experiences: Maureen suffered a nervous breakdown, and Pato feels now forced to emigrate to America in search of better working situation. McDonagh thus illustrates contemporary Ireland as a country unable to support its inhabitants, who feel frustrated and angry. As Pato remarks: «... hopping across to that bastardizing oul place [London] every couple of months couldn't've helped» (p. 384). His voice speaks of pessimism and discontent, no future seems to make up for a past empty of meaning. Like Maureen states: «... that's Ireland, anyways. There's always someone leaving» (p. 384). This impotence that undermines the Irish identity is what suffuses McDonagh's play, and takes readers/audience into a world bereft of hope.

Whether recovering the tradition of «angry young man/woman drama», or representing the nineties «in-yer-face theatre», McDonagh's TheBeauty Queen distills the frustration of its protagonists for a meaningless new world that has trapped their dreams into a murky reality. As Mel Kenyon once stated, «There is a moment. There was a moment» ${ }^{10}$, where political instability and cultural readjustment emerge in a new theatrical form that explores the existing disappointment and cruelty of contemporary Ireland.

\section{MCDONAGH's GOTHIC DRAMA: THE HALLMARK OF THE «IRISH PSYCHO» ${ }^{\mathrm{II}}$}

«Before poetry can be human again, it must learn to be brutal»

(Synge, quoted in O’Driscoll, 1971: 14)

Following the Irish Renaissance tradition, many Irish contemporary authors use horror and violence to criticize the nature of their national identity, and expose their bleak views for the Irish future. Authors such as McCabe, Patterson, Banville, and McDonagh invite to readings where violence appears as a common frame to understand the world today. In that respect, Lanters ${ }^{12}$ compares the two groups of writers, Renaissance and contemporary, and argues:

The mood of the country had changed. Whereas the writers and artists of the Celtic Revival had played an active part not just in reflecting but in actually creating a vision of the future of Ireland, the Free State, with its narrowly defined moral and cultural code, fearful of independent and creative thought, forced its literary figures into an oppositional and increasingly marginalized role (Unauthorized Versions, 2000: 2).

${ }^{10}$ Mel Kenyon, interview with author Ken Urban, Casarotto Ramsey Agency, London, 10 April 2001. http://kenurban.org/pdf/NTQ_CB.pdf

${ }^{11}$ As coined by Lilian Chambers \& Eamonn Jordan in The Thetre of Martin McDonagh: A World of Savage Stories, Carysfort Press, Dublin, 2006: 114

12 José Lanters. Unauthorized Versions: Irish Menippean Satire, 1919-1952. Washington: Catholic University of America Press, 2000. 
In «Abjection, Nationalism, and the Gothic», Robert Miles supports that nationalism and the Gothic emerge together to mark the nation's boundaries in terms of what the nation is not. For Luke Gibbons, as he argues in Gaelic Gothic, the Irish became associated with monstrosity and degeneration as a consequence of the English Gothic aversion towards Catholicism and the Irish ${ }^{13}$. As Judith Halberstam argues, the Gothic novel «produces an easy answer to the question of what threatens national security and prosperity», which is basically the appearance of «the monster» (p. 3). Therefore, the Gothic contributes to identify the national identity, and facilitates recognition of those elements (monsters) which must be expelled and killed off to preserve the national welfare. According to Judie Newman, monsters are, however, created by society, and for that reason society should be blamed for. In her article «Postcolonial Gothic: Ruth Prawer Jhabvala and the Sobhraj Case,» Newman maintains that «Gothic motifs are exceptionally prevalent in postcolonial fiction» (p. 171). These gothic elements enable McDonagh to present an explicit critique of contemporary Irish society. The combination of tradition, repression, and anxiety will contribute to liberate the monster through a release of brutality. For Halberstam, this paradigm reveals that,

Within postmodern Gothic we no longer attempt to identify the monster and fix the terms of his/ her deformity, rather postmodern Gothic warns us to be suspicious of monster hunters, monster makers, and above all, discourses invested in purity and innocence. The monster always represents the disruption of categories, the destruction of boundaries, and the presence of impurities and so we need monsters and we need to recognize and celebrate our own monstrosities (1995: 27).

Monsters can thus be seen as possible alternatives or new identities in societies where desires and anxieties are confronted. This transformation shows confused personalities that mirror tradition and its brutal offspring as a haunting spinning wheel that deters them to «unwind the messy skein of identities and separate out the good from the ugly, the bad from the pure, the perverted from the kind, the sexual from the spiritual, the beautiful from the unhealthy» (Halberstam, 1995: 59).

McDonagh also recovers the horror tradition formerly established through classic films in order to intensify the brutality that derives from continual frustration (Waters, 1984: 155). In The Beauty Queen, the scene in which Maureen deliberately torments and punishes her mother has a clear reminiscence in Hitchcock's film «Psycho» ${ }^{14}$. The reader/audience can easily identify the image of the dead mother sitting on the rocking chair «which rocks back and forth of its own volition» (p. 414), suddenly slumping forward and showing her hollowed skull, «A red chunk of skull hangs from a string of skin at the side of her head» (p. 415). This revelation recalls immediately the film which purposely serves to disturb and shake the reader/audience's expectations, signaling the transition to horror and the Gothic. At this point, Maureen has performed Norman Bates' story from a female point of view. Both characters share the contemptuous relationship with their mothers in a claustrophobic environment, and a sickening sexual repression

\footnotetext{
${ }^{13}$ For further reading: Luke Gibbons, Gaelic Gothic: Race, Colonization, and Irish Culture. Research Papers in Irish Studies 2, Galway, Arlen House, 2004.

${ }_{14}$ Nicholas Grene also claims as a possible source Beckett's Rockababy («Ireland», p. 301), but since Psycho appeared much earlier, Beckett, most likely, might have also taken it from the film.
} 
that eventually will drive them to matricide. For Maureen and Norman, the killing of their mothers is the killing of their frustration and sexual repression. However, as it has been exposed before, despite both have taken out their scapegoats, the internalization of such murders will dissolve their personalities into a blurring image of their own mothers. Hommi Bhabha (1990) defines the figure of the outcast as «discriminatory» (p. 173), and he articulates a model of «hybridity» that, like monstrosity, unsettles borders and categories ${ }^{15}$. The result of that new hybrid entity also finds a traditional element in the Gothic genre. The figure of the doppelganger, or double, can thus be seen as a self-concealed (split-personality) character, or as an alternative choice to project the self into another body. In the case of Maureen and Norman, both adopt their mothers' appearance by wearing their dresses and becoming them, and consequently becoming murderers. The ghost of Maureen's mother, formerly presumed at the beginning of the play «...you'll never be dying. You'll be hanging on forever just to spite me» (p. 379), still haunts Maureen, and is made present in the empty rocking chair that «rocks gently» (p. 425) after Mag's death, and in her own transformation: «The exact fecking image of your mother you are, sitting there pegging orders...! (p. 424). The rocking chair and the black dress are now Maureen's new image. Mag has finally taken over and superseded her personality, driving Maureen to insanity, and thus making her become her own image. In sitting on her mother's chair, Maureen literally accepts her defeat, and sees her present and future doom and bleak. She has murdered only to become all that from which she desired to escape. She sits, «refusing to go on....» ${ }^{16}$ (Esslin, 1968: 195). She has ended hope, and without hope, the hall of mirrors is endless.

According to Murray (1997), McDonagh dramatizes the story in three acts which are «both instrumental in defining and sustaining national consciousness» ${ }^{17}$. As Julia Kristeva remarks in Nations without Nationalism, «the cult of origins is a hate reaction» which progressively leads to a «persecuting hatred» (1993: 2-3), and she concludes: «only a thorough investigation of our remarkable relationship with both the other and strangeness within ourselves can lead people to give up hunting the scapegoat outside their group» (p. 51). However, this recurrent association of «the return of the repressed» emerges from the general unconscious to show what society has neglected, refused to acknowledge, and thus it shows the consequences of such abandonment. In words of Ian Butler:

It is the ordinary, the apparently normal, the beautiful which horrify-the monstrous and distorted which compel our respect, our sympathy, ultimately our affection. The visible beauty conceals the unseen evil, the visible horror is the real goodness (quoted in Hawkins, 2000: 152).

For Lanters ${ }^{18}$, works like The Beauty Queen «act as agent provocateurs in the national debate,» by means of «contrariness to accepted pieties» in order to «raise questions about

15 For further reading, see Homi Bhabha. «Signs Taken for Wonders: Questions of Ambivalence and Authority under a Tree Outside Delhi, May 1871.» Race, Writing, and Difference. Eds. Henry Louis Gates, Jr. and Kwame Anthony Appiah. Chicago: University of Chicago Press Journals, 1992: 163-184.

16 In reference to Genet's theatre, McDonagh captures the image of Maureen helpless and alone.

17 Christopher Murray. Twentieth-Century Irish Drama: Mirror Up to Nation. Manchester: Manchester University Press, 1997: 3.

18 José Lanters. «Playwrights of the Western World: Synge, Murphy, McDonagh.» A Century of Irish Drama: Widening the Stage. Eds. Stephen Watt, Eileen Morgan, and Shakir Mustafa. Bloomington, Indiana UP, 2000: 204-222. 
the representation of identity, including Irish national identity» (2000: 222). McDonagh's use of unsettling images and ferocious acts pursues to reveal the moral corruption and decay of the Irish society in general (Chambers \& Jordan, 2006: 210). It is this aspect what troubles the reader/audience about the play, because McDonagh persuades them to feel sympathy for Maureen, a horrific monster who, like Norman Bates, kills her mother. Furthermore, this monstrosity is also arisen in the reader/audience indicating that, like the protagonists, they could be recognized as irreversibly flawed and monstrous too. McDonagh thus breaks the atavistic desire to identify cruelty among us, but apart from us. Similarly, McMullen (2004) analyses the causes that are driving contemporary writers to «critically interrogate the hidden wounds of the nation's past and to think about moving on. Yet there remains a persistent anxiety, stated and unstated, about «What kind of people are we becoming?» (p. 128).

\section{CONCLUSion}

Martin McDonagh's The Beauty Queen of Leenane combines exceptionally the traditional canon of Irish drama with innovative elements of popular genres, such as Gothic and American horror films. McDonagh speaks of the dark undercurrents of domestic life with blunt honesty and shocking brutality. His deep awareness of Irish identity discloses a world of anxiety, frustration, isolation, and exile. His pessimistic voice is as provocative as his plays, and his convincing portrayal of contemporary rural Ireland plunders the traditional past to reformulate the ambiguous present. McDonagh stirs emotions that invite readers and audience to a critical debate about the history and traditions of a land that bespeaks irreversible changes. He generates a poignant reality where he continuously repudiates the social standards and moral codes. It is for us, readers/audience, to discover the deep relevance of his voice, for he has the ability to conjure the visible truth of a contemporary Irish society that must see itself without the distorting mask of excuse, or ignorance. In words of Esslin (1961), McDonagh, like Genet, «project[s] the feeling of impotence of the individual caught up in the meshes of society» (p. 157).

\section{BIBLIOGRAPHY}

Banville, John (1989). The Book of Evidence. New York, Warner.

Barber, Benjamin R. «Jihad Vs. McWorld.» The Atlantic Monthly. March 1992. 10 Oct. 2012. www.theatlanticmonthly.com/politics/foreign/barjiha.htm

Bнавна, Hомі (1990). «DissemiNation: time, narrative, and the margins of the modern nation.» Nation and Narration. Ed. Homi Bhabha. London, Routledge, pp.: 291-322.

- (1994) «Signs Taken for Wonders: Questions of Ambivalence and Authority under a Tree Outside Delhi, May 1871.»

- (1992) Race, Writing, and Difference. Eds. Henry Louis Gates, Jr. and Kwame Anthony Appiah. Chicago: University of Chicago Press Journals, 1992. 163-184.

- (1994) «Introduction: Locations of Culture.» The Location of Culture. London: Routledge, 1994: 1-18. 
Brantley, Ben. «Enter 90's Anxieties Stage Right.» New York Times 7 June 1998: 11:1- 4. http://www.nytimes.com/1998/06/07/arts/theater-enter-90-s-anxieties-stage-right. html?pagewanted=all\&src=pm

Carroll, Clare and Patricia King, eds (2003). Ireland and Postcolonial Theory, Notre Dame, $\mathrm{U}$ of ND Press.

Chambers, Lilian And Jordan Eanonn (2006). The Theatre of Martin McDonagh: A World of Savage Stories, Dublin, Carysfort Press.

Diamond, Elin (1997). Unmaking Mimesis: Essays on Feminism and Theater, London, Routledge.

Diehl, Heath (200I). «Classic Realism, Irish Nationalism, and a New Breed of Angry Young Man in Martin McDonagh's The Beauty Queen of Leenane.» In The Journal of the Midwest Modern Language Association ,34, pp. 97-117.

Dolan, Jill (1991). The Feminist Spectator as Critic. Ann Arbor, Michigan UP.

- (1990) «Lesbian' Subjectivity in Realism: Dragging at the Margins of Struc-tures and Ideology.» In Performing Feminisms: Feminist Critical Theory and The-atre. Ed. Sue-Ellen Case. Baltimore: Johns Hopkins UP, 1990: 40-53.

Ellis, Bret Easton (1991). American Psycho, New York, Vintage.

Esslin, Martin (1991). The Theatre of the Absurd, New York, Doubleday and Company Inc.

Genet, JeAn (1982). The Maids, New York, Grove Press.

- (1964) The Thief's Journal, New York, Grove Press.

Gibbons, Luke (2004). Gaelic Gothic: Race, Colonization, and Irish Culture, Research Papers in Irish Studies 2. Galway: Arlen House.

- (1996) Transformations in Irish Culture. Field Day Essays and Monographs 2, Notre Dame: University of Notre Dame Press.

Grene, Nicholas. «Black Pastoral: 1990s Images of Ireland.» Litteraria Pragensia 20.10

- (2000). 23 Oct. 2012. http://www. komparatistika.ff.cuni.cz/litteraria/no20-0/grene.htm

- (2005) «Ireland in Two Minds: Martin McDonagh and Conor McPherson.» The Yearbook of English Studies: Irish Writing since 1950, pp.: 298-311.

Halberstam, Judith (1995). Skin Shows: Gothic Horror and the Technology of Monsters. Durham, Duke UP.

Hanafin, Patrick (2001). Constituting Identity: Political Identity Formation and the Constitution inPost-Independence Ireland. Aldershot, Dartmouth; Burlington: Ashgate, 2001.

Hawkins, Joan (2000). Cutting Edge: Art-Horror and the Horrific Avant-Garde. Minneapolis, University of Minnesota Press, 2000.

JAMESON, FredRIC (1986). «Third-World Literature in the Era of Multinational Capitalism.» Social Text 15, pp.: 65-88.

Jeffers, Jennifer M (2002). The Irish Novel at the End of the Twentieth Century: Gender, Bodies, and Power. New York, Palgrave.

Kiberd, Declan (1995). Inventing Ireland: The Literature of the Modern Nation. Cambridge, Harvard UP.

- (2001)«Strangers in their Own Country: Multi-Culturalism in Ireland.» Multi-Culturalism: The View from the Two Irelands. Edna Longley and Declan Kiberd. Cork, Cork UP, pp. 45-78.

Kramer, Mimi (1997). «Three for the Show.» Time 4 Aug. pp.: 71-72.

Kristeva, Julia (1993). Nations without Nationalism. Trans. Leon S. Roudiez. New York, Columbia UP.

- (1982) Powers of Horror: An Essay on Abjection. Trans. Leon S. Roudiez. New York, Columbia UP.

Lady Gregory (1914). Our Irish Theatre: A Chapter of Autobiography, G. P. Putnam's Sons, New York and London. 
Lanters, José (2000). «Playwrights of the Western World: Synge, Murphy, McDonagh.»A Century of Irish Drama: Widening the Stage. Eds. Stephen Watt, Eileen Morgan, and Shakir Mustafa. Bloomington, Indiana UP, pp.: 204-222.

- (2000) Unauthorized Versions: Irish Menippean Satire, 1919-1952. Washington, Catholic University of America Press, 2000.

McBride, IAN (2001). «Memory and National Identity in Modern Ireland.» History and Memory in Modern Ireland. Ed. Ian McBride. New York, Cambridge UP. Pp.: 1-42.

McDonagh, Martin (1999). Current Biography Yearbook 1998. New York, H. W. Wilson, pp.: 419-422.

- The Beauty Queen of Leenane, London, Methuen Drama, 2001.

McMullen, Kim. «New Ireland/ Hidden Ireland.» The Kenyon Review 26.2, 2004: 126-149. Lion. Proquest. UNC Lib. System, NC. 3 Nov. 2012. http://lion.chadwyk.com

Miles, Robert (2001). «Abjection, Nationalism, and the Gothic.» The Gothic. Ed. Fred Botting. Essays and Studies 54. Cambridge, D.S. Brewer, pp.: 47-70.

Murray, Christopher (1997). Twentieth-Century Irish Drama: Mirror Up to Nation. Manchester, Manchester UP.

O'DrisCOLl, ROBERT (1971). «Introduction.» in Theatre and Nationalism in Twentieth-Century Ireland. Ed. Robert O'Driscoll. Toronto: Toronto UP, pp.: 9-20.

O'Toole, Fintan (1998). «Shadow Over Ireland.»in American Theatre, July/August, pp.: 16- 19.

Newman, Julie (1996). «Postcolonial Gothic: Ruth Prawer Jhabvala and the Sobhraj case.» Modern Gothic: A Reader. Eds. Victor Sage and Allan Lloyd Smith. Manchester, Manchester UP, pp.: 171-187.

Psycho. Dir. Alfred Hitchcock. Paramount, 1960.

Sage, Victor and Allan Lloyd Smith, eds (1996). Modern Gothic: A Reader. Manchester, Manchester UP.

Schechner, Richard (1977). Essays on Performance Theory, 1970-1976. New York, Drama Book Specialists.

Urban, Ken (2004). «Towards a Theory of Cruel Britannia: Coolness, Cruelty, and the 'Nineties», New Theatre Quarterly, 20, pp.: 354-372.

Waters, Maureen (1984). The Comic Irishman. Albany, State University of New York Press.

Watson, G.J (1979). Irish Identity and the Irish Revival: Synge, Yeats, Joyce and O'Casey. London: Croom Helm; New York, Barnes \& Noble.

Williams, Linda (1991). «Film Bodies: Gender, Genre, and Excess.» Film Quarterly 44.1 Summer, pp.: 2-13. 